Maastricht Graduate School of Governance (MGSoG)

\title{
Girls in transition
}

\section{How to build evidence and gain insight?}

\author{
Keetie Roelen
}

April 2010

Working Paper

2010WP013

\section{Maastricht Graduate School of Governance (MGSoG)}




\section{Maastricht Graduate School of Governance}

The 'watch dog' role of the media, the impact of migration processes, health care access for children in developing countries, mitigation of the effects of Global Warming are typical examples of governance issues issues to be tackled at the base; issues to be solved by creating and implementing effective policy.

The Maastricht Graduate School of Governance, Maastricht University, prepares students to pave the road for innovative policy developments in Europe and the world today.

Our master's and $\mathrm{PhD}$ programmes train you in analysing, monitoring and evaluating public policy in order to strengthen democratic governance in domestic and international organisations. The School carefully crafts its training activities to give national and international organisations, scholars and professionals the tools needed to harness the strengths of changing organisations and solve today's challenges, and more importantly, the ones of tomorrow.

\section{Authors}

Keetie Roelen, PhD, Research fellow

Institute of Development Studies (IDS)

Centre for Social Protection, Brighton, UK

Email: k.roelen@ids.ac.uk

http://keetieroelen.wordpress.com

\section{Mailing address}

Universiteit Maastricht

Maastricht Graduate School of Governance

P.O. Box 616

6200 MD Maastricht

The Netherlands

\section{Visiting address}

Kapoenstraat 2, $6211 \mathrm{KW}$ Maastricht

Phone: +31433884650

Fax: +31433884864

Email: info-governance@ maastrichtuniversity.nl 


\section{Introduction}

Poverty is an undesirable and, to many, an unacceptable phenomenon. A wide range of studies has suggested that the hardship of poverty is even more undesirable when it concerns children due to its far-reaching short-term and long-run negative implications (see e.g. Wagmiller, Lennon, Kuang, Alberti and Aber 2006; Haveman and Wolfe, 1995; Brooks-Gunn and Duncan, 1997; Duncan and Brooks-Gunn, 1997; Esping-Andersen and Sarasa, 2002). The increased acknowledgement that children deserve a special focus in the debate on poverty has encouraged the development of child-specific poverty approaches and measures (see Roelen and Gassmann, 2008; Roelen et al., 2009a). Generally, these child poverty approaches are developed for children at large, with limited diversification between age groups (Roelen, 2010). Nevertheless, an increasing body of research postulates that that the timing of poverty during childhood matters (Wagmiller et al., 2006; Duncan and Brooks-Gunn, 1997). For example, low levels of income and the receipt of welfare in the early childhoodperiod have been found to have a greater impact on school dropout than it does in other periods (Duncan and Brooks-Gunn, 1997; Duncan et al., 1998). Moreover, deep and persistent poverty in early childhood is likely to have more perverse effects in comparison to such episodes in later years of life (Duncan and Brooks-Gunn, 2000). Despite the notion that age matters, it has only led to a limited reflection in poverty measures.

Borrowing insights from other disciplines, we learn that adolescence is a particular stage in life with specific characteristics in terms of physical maturity, cognitive capacity and social skills (Bearinger, Sieving, Ferguson and Sharma, 2007) that might render the need for an adolescent-specific perspective in the analysis and assessment of their situations. Igra and Irwin (1996) postulate that "Normal adolescent development encompasses increasing independence, autonomy from the family, greater peer affiliation and importance, sexual formation, and physiological and cognitive maturation" (pp. 39). Psychological theory puts forward that adolescence is the decisive period in one's life for the formation of identity and the development of personality (see Erikson, 1968). Adolescence as a life stage is also of utmost interest to behavioral scientists as it is characterized by risk-taking behavior (Igra and Irwin, 1996). This type of conduct refers to behaviors that potentially damage one's health and leads to higher levels of morbidity and mortality amongst adolescents, such as drug and alcohol use. An issue relating to both the formation of identity as well as risk-taking behavior is the development of sexuality, sexual interactions and agency, especially in relation to girls (Impett and Tolman, 2006). Erikson (1968) further argues that due to technological advances that have increased the time span between 
early school life and one's access to the labor market, adolescence has gained increased significance as a separate life stage in the second half of the twentieth century. The awareness that well-being during adolescence can lead to positive behavioral change and consequently to better outcomes for the individual and the society has resulted in increased attention for adolescents in recent years in the debate on poverty reduction and development (Herrera, 2006). Moreover, the generation of adolescents has never been as big in history before with almost half of the world's population being younger than 25 years of age (Bearinger et al, 2007, Kleinert, 2007). Nevertheless, the emphasis that adolescents received as special focus group in the disciplines of psychology and behavioral science, amongst others, can not be observed in the field of poverty measurement and analysis.

This paper aims to address this gap within the debate on poverty and well-being measurement. It presents an explorative study to assess and investigate the issues related to the measurement of multidimensional poverty and well-being of a specific groups in society, delineated by age and gender, namely adolescent girls. Building evidence and gaining insight into their state of life is a pre-requisite to understand and address the issues they face. This paper applies the generic construction process that was developed by Roelen et al (2009a) to guide the development of multidimensional child poverty approaches to assess the possibilities of capturing the special situation of adolescents. Furthermore, it considers the MICS household survey of Vietnam to investigate the empirical implications.

The remainder of the paper is structured as follows: firstly, we provide an indicative but non-exhaustive review of existing studies on poverty and well-being with a special focus on adolescents. Second, we explore the theoretical options of formulating an approach that is tailored to the context of adolescent girls by using the generic construction process as a guiding framework. Next, the theoretical disposition is extended by an empirical investigation on the basis of Vietnamese household survey data. Finally, we conclude by putting forward options for future research.

\section{Adolescence, poverty and well-being}

A broader interpretation of poverty and well-being points towards an array of studies on the subjective life satisfaction of children and adolescents within the field of psychology that has been undertaken since the beginning of the 1990's. Seminal work by Huebner (1991, 1994) on the Multidimensional Students' Life Satisfaction Scale (MSLSS) has inspired a body of research that is now widespread and well established. The MSLSS and other life satisfaction scales are used to assess the satisfaction of school-aged children and students in different life satisfaction domains, including school, family, friends and living environment (Huebner et al., 2000; Huebner, 2004). Bender (1997)) argues that these subjective measures of life satisfaction should also be adjusted to the developmental phase of the child/adolescent as self-concepts 
become more differentiated with age and inherent cognitive development. The notion of the need for age-appropriate scales for the measurement of life satisfaction can thus be said to have inspired a body of research salient to those aspects reflective of different stages if life.

A review of the wide range of existing evidence on child poverty from a social science or socio-economic perspective does not point towards the existence of a wide range of age-appropriate studies and suggests that the majority of approaches are developed for children at large, overarching children in all age groups (Roelen, 2010). Unless the purpose of the child poverty approach clearly stipulates the analysis of a specific age group, a one-size-fits-all type of concepts is applied. The comparative child poverty studies by Gordon et al. (2003a, 2003b) and Bradshaw et al. (2006) as well as the country-specific studies by Noble et al. (2006) and Roelen et al. (2009a, 2009b) employ a single concept for children in different stages of childhood. A very limited number of studies have focused on children in specific age groups and adolescents in particular. Moore et al. (2008b) present a rare example of an agespecific child poverty study with an age-appropriate construct of child poverty by focusing on middle childhood (ages 6-11). The rationale for this age-specific study follows from the acknowledgement that middle childhood is a unique developmental period and that a lack of attention can lead to harmful consequences in adolescent and adult life (Moore et al., 2008b). The authors emphasize that further testing of the scarce and scattered age-specific studies on child well-being is necessary (Moore et al., 2008). The study by Moore et al. (2008b) builds on work by Moore et al. (2008a), who construct a child well-being index for children in middle childhood (6-11) and in adolescence (12-17). Although the theoretical framework is based on the premise that separate items should be included for different age groups in order to be "[...] were reflective of the associated developmental capacities and needs of early and middle childhood and adolescence" (Moore et al., 2008a), the same set of indicators are de facto used for both age groups due to data availability issues. In comparison, children in middle childhood were generally found to have higher levels of well-being than adolescents. Trzcinski and Holst (2008) investigated subjective well-being amongst 17-year olds in Germany and possible factors that might explain differences amongst young people in transition to adulthood. The study's conceptual model largely builds on the life satisfaction literature by Huebner and others. Subjective well-being was captured by 17-year olds' own assessment of their life satisfaction whilst explanatory constructs included personal relationships, family composition, income and economic hardship and employment. Predictive factors of adolescent subjective well-being were generally found to overlap with predictive factors of adult subjective well-being.

In sum, the range of studies on age-specific studies investigating well-being, poverty and vulnerability is scarce and scattered. The majority of research can be found in psychological, developmental or behavioral literature, whilst very little evidence is 
available from a more socio-economic perspective. Evidence on adolescents is limited and, to our knowledge, gender-sensitive constructs are largely unexplored.

\section{Exploring the options}

This section presents a theoretical exploration for the development of an approach that considers the situation of adolescents and adolescent girls in particular. As a guide for this exploration, we apply the generic construction process as developed by Roelen et al. (2009a). This construction process can be used as a guide to ensure explicit and transparent decision-making at every step along the process. These steps include the identification of the rationale and purpose of an approach, the formulation of a conceptual framework, the choice of domains and indicators and the development of outcome products in the form of poverty measures. Each of these steps is subject to value judgments and follows from decisions made at previous steps. As such, the development of a poverty approach is an inherently normative process and path dependent. A careful, explicit and transparent process will ensure that the concurrent child poverty approach and its outcomes are less prone to misunderstandings and misinterpretations (Roelen et al., 2009a; Alkire, 2008).

\section{Rationale and purpose}

The rationale behind the construction of a poverty approach geared towards adolescent girls is to build evidence and gain specific insight into the situation of this specific group in society. Adolescents have gained increased attention and importance within the development policy and poverty reduction debate resulting from the acknowledgment of the crucial role they can play within these processes (Herrera, 2006). However, a review of literature suggests that a very limited number of attempts have been undertaken in the existing of body of research to explore the specific situation of adolescents, and adolescent girls in particular, in terms of poverty and well-being. This paper aims to investigate the extent to which a multidimensional poverty approach can be geared to capture the situation of adolescent girls, how to overcome conceptual and empirical constraints and to build evidence and gain insights. The situation of adolescent girls in Vietnam is used as a specific case study.

\section{Conceptual framework}

A first issue to clarify within the discussion on the conceptual framework concerns the specific age brackets that are considered to be reflected by adolescence. There is no clear definition about the specific age boundaries that delineate the life stage of adolescence (Herrera, 2006) but there is widespread consensus that it ranges from 10 to 18 or 19 years of age (see e.g. Sells and Blum, 1996; Impett and Tolman, 2006; WHO, 2010). The first part of this period can be referred to as early adolescence whilst the second part as late adolescence (Impett and Tolman, 2006). The age parameters of youth are usually wider and, depending on the definition, range from 12 or 15 years to 24 years of age (Herrera, 2006). We will follow the definition of 
adolescence and focus on girls aged 10 to 19 years of age. The construction of adolescence as a distinct group, and thereby separating them from children and adults as natural groups, has also been criticized for its ignorance of the cultural, social and historical context and focus on adolescents as a primarily problematic group (see e.g. Lesko, 1996). We acknowledge these concerns and realize that a degree of generalization and normative judgment on what is normal and deviant behavior is inherent to the delineation of different groups in society along any lines. Nevertheless, we believe that the widespread evidence from different disciplines that individuals aged 10 to 19 years are confronted with issues specific to their age can not be ignored and calls for a translation into a specific concept of poverty and well-being.

Considering the many changes occurring within the period of adolescence and the transition from child- to adulthood that it represents, the construct of multidimensional poverty for adolescent girls might prove difficult to conceptualize. Two distinct conceptual constructs might be of relevance here, namely the notions of well-being versus well-becoming. The first concept focuses on current life outcomes as a state in and of itself whilst the latter builds on the notion that individuals (children or adolescents) should be prepared for the future and adult life (Roelen, 2010; Ben-Arieh, 2000). As adolescence represents the very transition from one life stage to another, the majority of studies seem to focus on adolescents in their role as future adults rather than on current outcomes and their intrinsic value (see White, 2002). The increased awareness of the importance of adolescents and youth in the development debate reflects exactly that; their crucial role in " [...] forging more stable, democratic and economically prosperous societies" (Herrera, 2006, pp. 1426). And although behavioral studies acknowledge the threats of risk-taking behavior for adolescents' health and well-being in the present, they also emphasize the adverse negative consequences in adult life (see e.g. Igra and Irwin, 2006). Bearinger et al. (2007) state that [...] adolescents are the greatest hope for turning the tide against STI's, AIDS, and early pregnancy" (pp.1220). Qvortrup (1999) expresses the fear that a sole focus on well-becoming "[...] justifies any type of life for children, provided the end result - that is, the adult person - exhibits positive values on a set of success criteria". The intrinsic importance of child well-being also follows the concept of children's rights (Ben-Arieh 2000) and human rights. Moreover, in his seminal work on the basic needs approach, Streeten (1984) already postulated that "The consumption aspects and the investment aspects of human resource development thus reinforce each other" (pp. 976). The intrinsic value as well as future importance of child and adolescent poverty and well-being calls for an interest in present and future childhood and adolescence (Qvortrup, 1997). In terms of the conceptual framework underlying this study, we propose a hybrid construct that incorporates issues pertaining to the current well-being and future well-becoming of adolescent girls. 
The human and child rights as well as basic needs approaches might consequently serve as useful frameworks for the identification of issues relevant for adolescent girls' current well-being and future well-becoming. Inevitably, these will include a set of issues that are not specific to girls in adolescence only but are relevant for all individuals in society, such as basic needs relating to housing conditions, clean water and hygienic sanitation facilities. Borrowing insights from other disciplines, we might also be able to identify those issues that are relevant particularly for adolescent girls. Risk-taking behavior is one of such issues pertaining particularly to adolescents (i.e. Furby and Beyth-Marom, 1992; Igra and Irwin, 1996). Such behavior includes activities that are undertaken by adults as well, such as the use of alcohol and drugs or the driving a car, but adolescents pursue them in a way that entails greater risks (Furby and Beyth-Marom, 1992). As a consequence, risk-taking behaviors and negative outcomes of early pregnancy and STI's have been found to be the most important threats for adolescents' health and well-being during adolescence as well as into adulthood (Igra and Irwin, 1996; Bearinger et al., 2007). Bearinger et al. (2007) state that $[\ldots]$ the immature reproductive and immune systems of adolescent girls translate to increased susceptibility to STI and HIV transmission; pregnancy and delivery for those with incomplete body growth exposes them to problems that are less common in adult women" (pp. 1220). The issue of reproductive health can thus be considered an important issue and source of vulnerability for adolescent girls pertaining to their current level of well-being as well as future well-becoming. Developmental theory also postulates that other aspects, such as family and peerrelation, education and constructive leisure activities, are particularly relevant in adolescent life (see Barber, Eccles and Stone, 2001). The role of these aspects in the formation of identity and development of sense of self during adolescence (Erikson 1986), is what makes them so particularly relevant for this period in life.

In sum, the proposed concept for female adolescent poverty and well-being is multidimensional in nature, a hybrid between the constructs of well-being and wellbecoming and includes issues both particular to adolescent girls as well as relevant for all individuals in society. Empirically, the situation of adolescent girls might be difficult to measure as data in household surveys is often collected for respondents differentiated by age. The age boundaries of the various questions might not be in line with those that denote the period of adolescence. Given the blurred relation between child- and adulthood, indicators might not be available for the adolescent group as a whole but only for limited age brackets.

\section{Domains and indicators}

The choice of domains and indicators can be instigated by a number of different selection mechanisms (Roelen at al. 2009a; Alkire, 2008; Biggeri, 2007). These mechanisms include public consensus, expert opinions and data availability, amongst others. Generally, a combination of selection mechanisms is used to arrive at a set of 
domains and indicators for a given poverty approach. Public consensus documents, existing studies and an assessment of the available data informed the choice of domains and indicators to reflect the situation of adolescent girls. Public consensus documents include the Convention of the Rights of the Child, the Universal Declaration of Human Rights and the Millennium Development Goals. These do not specifically point towards issues exclusively relevant for adolescent girls but point towards a range of basic needs such as food, clothing, housing, medical care, social services and social security (Article 25, UDHR). In terms of previous studies, we build on the set of items proposed by Moore et al. (2008a) for the measurement of well-being in middle childhood and adolescence. The domains include physical, psychological, social, educational/intellectual, family, neighborhood, sociodemographic well-being. We adjust those for the developing country context, agespecificity and gender sensitivity when possible. We do not include measures reflecting the specific situation of the family, neighborhood or socio-demographic conditions in the construct of child well-being as we aim to use those for the explanation of differences in adolescent girl well-being outcomes. Finally, we assess the information available within the household survey from Vietnam. The specific survey employed for the empirical application is the Multiple Indicator Cluster Survey (MICS) from 2006. The Vietnam MICS is based on the standardized MICS surveys as technically supported by UNICEF. The first and second round was conducted in 1995 and 2000, while the third round was completed in 2006. The survey contains a range of questions especially focused on education, health, reproductive health, HIV/AIDS and is separated into a questionnaire for households, women of reproductive age (1549) and children under five. Regions were identified as the main sampling domains and the sample was selected in two stages, based on enumeration areas from the census. The sample consists of a total number of 10.861 households with 36.573 individuals out of which 8.574 are adolescents aged 10-19. There are 4.130 adolescent girls in this sample.

The final set of domains and indicators selected on the basis of these mechanisms are presented in Table 1. Ideally, they reflect the multidimensional nature of poverty and well-being faced by adolescent girls, issues of well-being in the present and wellbecoming in the future and issues pertaining to both adolescent girls in particular and all individuals in Vietnam in general. The availability of information within the MICS proved to be a considerable constraining factor as the MICS survey primarily focuses on issues related to objective well-being and does not include many questions on respondents' perception or feelings about specific issues. The final set consists of four domains, namely education/intellectual, health, social and living environment, and a total of 13 indicators. Note that indicators are not equally formulated positively or negatively and that concurrent indicator rates reflect a positive or negative situation dependent on the formulation of the specific indicator. 
Table 1 Domains and indicators

\begin{tabular}{|l|l|l|}
\hline Domain & Indicator & Observed for \\
\hline Education/intellectual & gross enrollment & $\begin{array}{l}\text { all adolescent girls and } \\
\text { boys, aged 10-19 }\end{array}$ \\
\hline & primary school completion & $\begin{array}{l}\text { adolescent girls and } \\
\text { boys, aged 13-19 }\end{array}$ \\
\hline Health & literacy & $\begin{array}{l}\text { adolescent girls, aged } \\
15-19\end{array}$ \\
\hline & given birth during adolescence & $\begin{array}{l}\text { adolescent girls, aged } \\
15-19\end{array}$ \\
\hline Social & knowledge about HIV/AIDS & $\begin{array}{l}\text { adolescent girls, aged } \\
15-19\end{array}$ \\
\hline Living environment & $\begin{array}{l}\text { attitude towards domestic violence } \\
\text { (acceptance of hitting wife) }\end{array}$ & $\begin{array}{l}\text { adolescent girls, aged } \\
15-19\end{array}$ \\
\hline & access to safe drinking water & $\begin{array}{l}\text { all adolescent girls and } \\
\text { boys, aged 10-19 }\end{array}$ \\
\hline & access to hygienic sanitation & $\begin{array}{l}\text { all adolescent girls and } \\
\text { boys, aged 10-19 }\end{array}$ \\
\hline & living in dwelling with electricity & $\begin{array}{l}\text { all adolescent girls and } \\
\text { boys, aged 10-19 }\end{array}$ \\
\hline & living in dwelling with proper roof & $\begin{array}{l}\text { all adolescent girls and } \\
\text { boys, aged 10-19 }\end{array}$ \\
\hline & living in dwelling proper floor & $\begin{array}{l}\text { all adolescent girls and } \\
\text { boys, aged 10-19 }\end{array}$ \\
\hline & living in dwelling with TV & $\begin{array}{l}\text { all adolescent girls and } \\
\text { boys, aged 10-19 }\end{array}$ \\
\hline & living in dwelling with computer & $\begin{array}{l}\text { all adolescent girls and } \\
\text { boys, aged 10-19 }\end{array}$ \\
\hline & &
\end{tabular}

\section{Empirical investigation}

To test the empirical applicability of the conceptual framework as outlined in the previous section, we provide descriptive statistics for a number of selected indicators in this section ${ }^{1}$.

\section{Education/intellectual domain}

The education and intellectual domain aims to capture adolescent girl's situations with respect to situation in terms of educational progress and intellectual standards. Three indicators were identified, namely gross enrollment, completion of primary school and literacy. Whilst the first indicator is observable for adolescent girls of all ages, the primary school completion indicator and literacy indicator are only observed for older adolescents. In case of primary school completion, this is due to the fact that girls younger than 13 years of age are simply not able to have concluded primary education yet. The question in the MICS survey referring to literacy is only directed towards girls of 15 years and older and can thus only be observed for those.

Estimates for literacy rates amongst adolescent girls aged 15-19 in the appendix indicates that literacy is widespread and that there is fairly little differentiation between different groups in society. Gross enrollment rates and primary school

\footnotetext{
${ }^{1}$ The results for all indicators can be found in the appendix.
} 
completion rates might allow for a more diversified picture of the situation of adolescent girls with respect to education. Figures 1 and 2 respectively display gross enrollment rates and primary school completion rates for adolescent girls and boys decomposed by area, region, ethnicity and age groups for Vietnam.

Figure 1 Gross enrollment rates in Vietnam

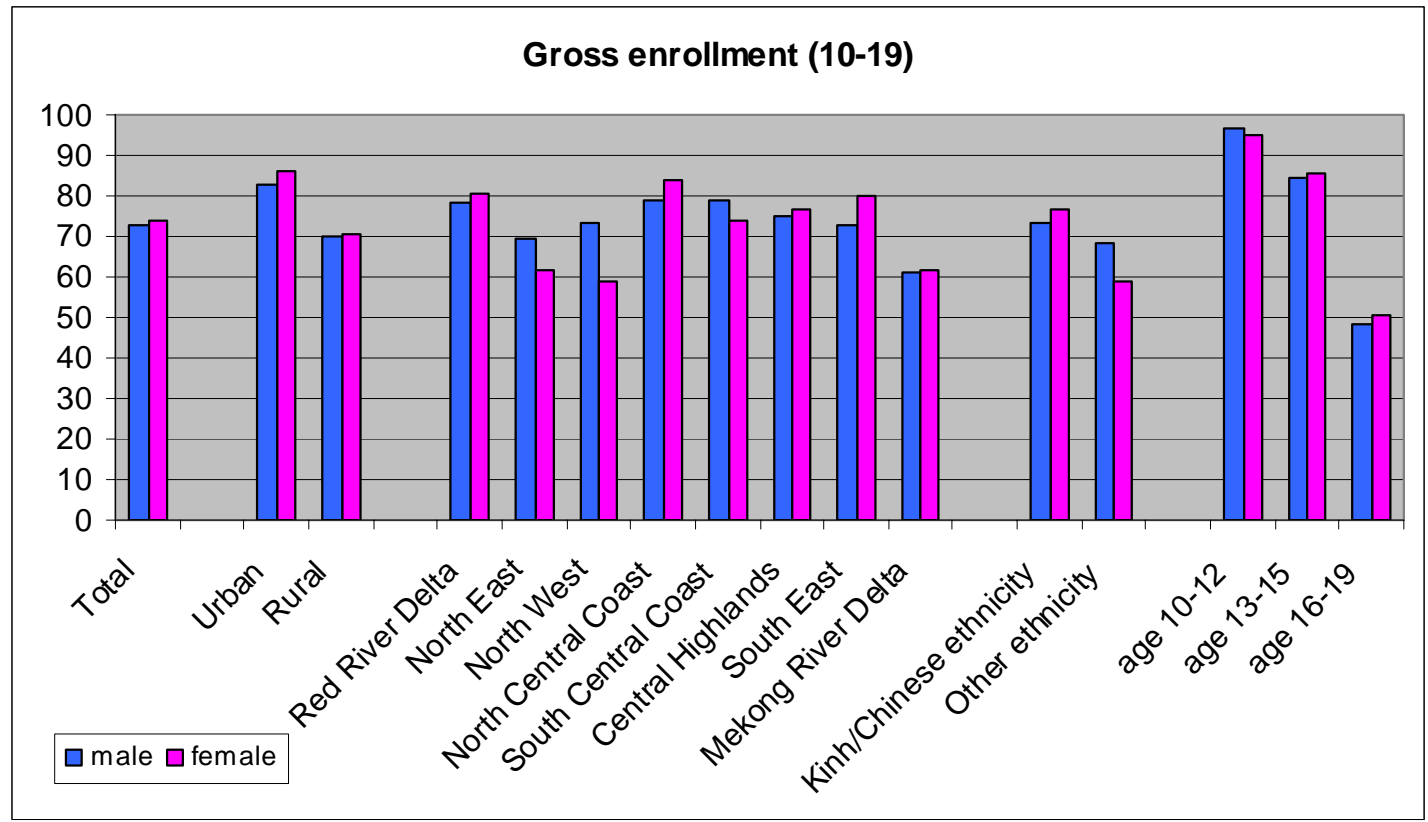

Source: author's own calculations from MICS 2006

Figure 2 Primary school completion rates in Vietnam

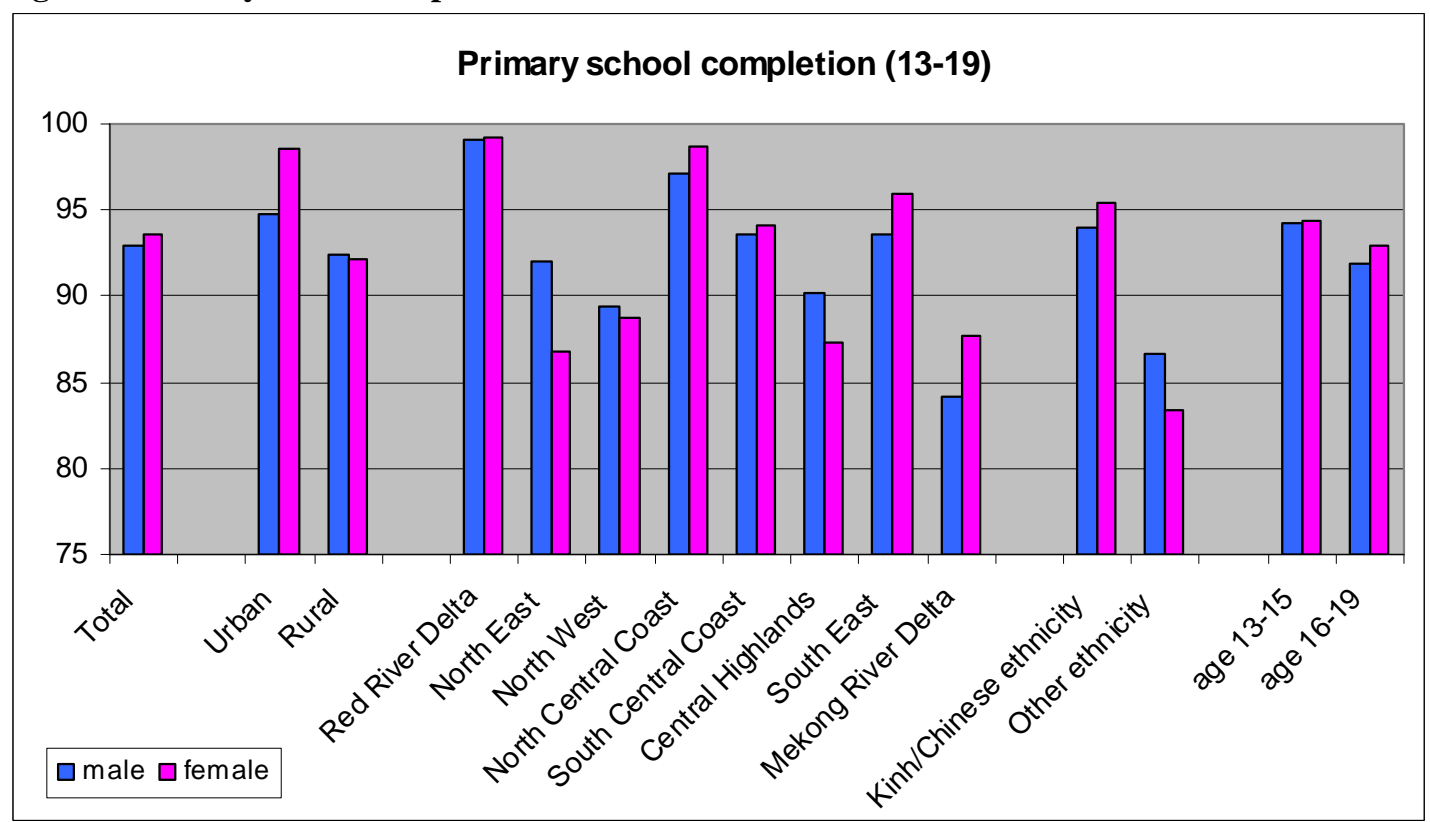

Source: author's own calculations from MICS 2006

Generally, we can observe an overall level of high well-being with respect to education for adolescent girls. The average gross enrollment rate for adolescent girls is 74 percent but this can be mainly attributed to a relatively low level of enrollment amongst older adolescent girls (aged 16-19). Primary school completion for adolescent girls averages about 94 percent for all girls aged 13-19. Given the availability of these education estimates for both girls and boys, we can also explicitly 
consider any degree of gender inequality within this domain. We do not observe any consistent degree of gender inequality with respect to education with a relatively disadvantaged position for either girls or boys. A closer look at the decomposition by area, region and ethnicity indicates that girls perform slightly better in the more affluent urban area and Red River Delta, North Central Coast and South East regions. By the same token, boys appear to be in a more advantaged position in the North East and North West regions and in the case of ethnic minorities.

\section{Health domain}

The health domain incorporates indicators on issues pertaining to reproductive health as well as access to health services and quality of care. The MICS data allows for the collection of fairly little evidence on health, especially for early adolescents. The first indicator under consideration is the proportion of adolescent girls that have already given birth to a baby. The estimates presented in the appendix indicate that this only represents a small proportion of adolescent girls aged 15-19 in Vietnam, averaging 3 percent. The second indicator, namely the knowledge about HIV/AIDS will be considered in closer detail here. This indicator is based on survey questions that evaluate women's knowledge about the transmission of or protection against HIV/AIDS. The questions included in this indicator include: "Have you heard of HIV/AIDS?', "Can HIV/AIDS be transmitted through witchcraft or supernatural means?", "Are you protected against HIV/AIDS by always using a condom?", "Is it possible for a healthy-looking person to have HIV/AIDS?" and "Can HIV/AIDS be transmitted through pregnancy?". An aggregate indicator is created by assuming that if an adolescent girl is able to answer correctly to at least 4 out of 5 questions, that she has knowledge about HIV/AIDS. Figure 3 represents a radar diagram, depicting the proportions of adolescent girls (15-19) with specific knowledge about HIV/AIDS by region. 
Figure 3 Knowledge about HIV/AIDS in Vietnam

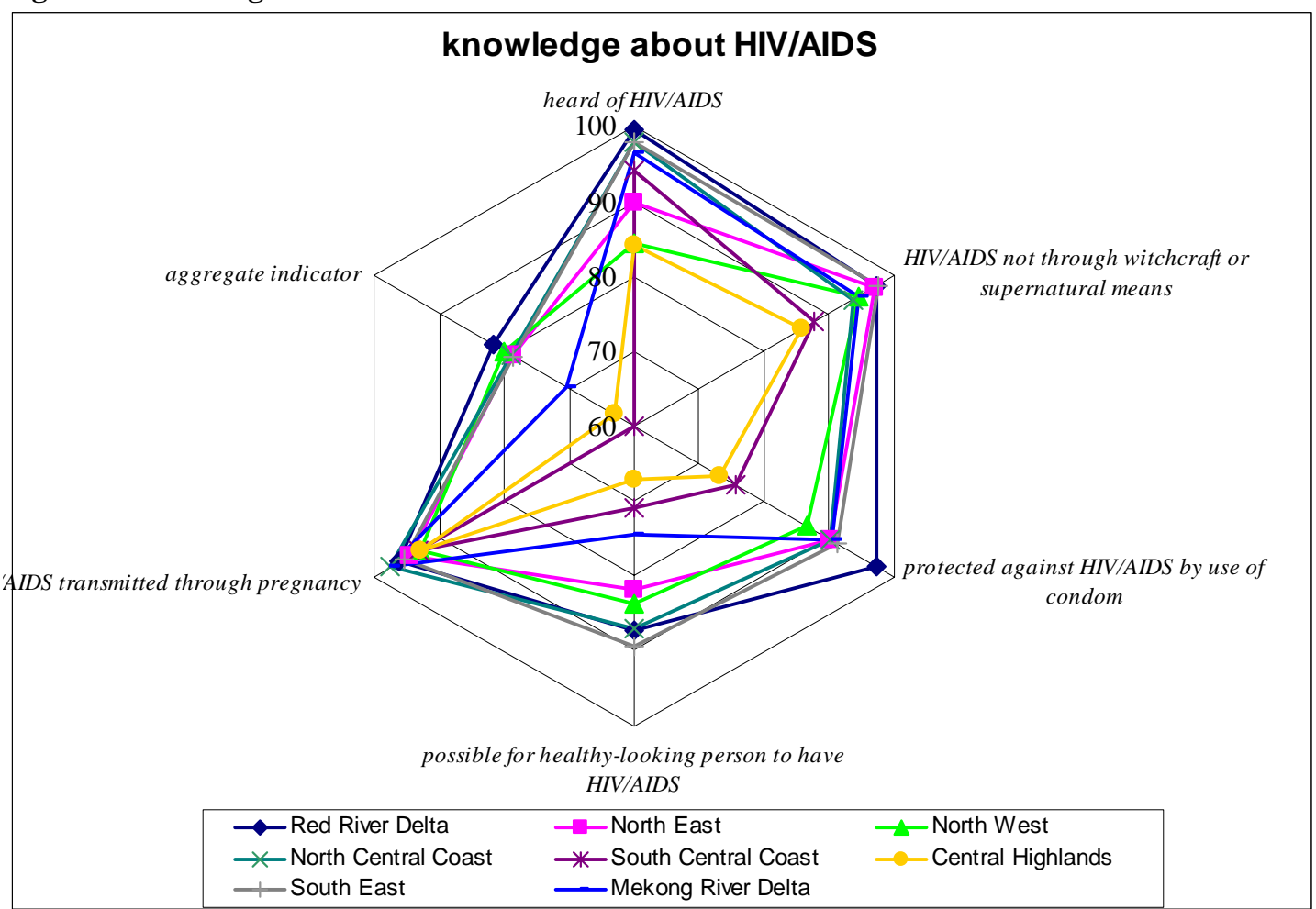

Source: author's own calculations from MICS 2006

A first observation from this radar diagram is the large dispersion by region for specific knowledge of HIV/AIDS. Whilst 90 percent of adolescent girls in all regions are aware that HIV/AIDS can be transmitted through pregnancy, these proportions range from 67 to 90 percent with respect to the possibility of a healthy-looking person to have HIV/AIDS. The specific distribution by region is also of interest; the Central Highlands and South Central Coast regions hold particularly large proportions of girls without specific knowledge of HIV/AIDS. These findings are rather surprising as these regions are usually amongst the average performers in terms of poverty or other areas of well-being and are not home to a particular population group with distinct beliefs or values. (see Roelen et al. 2009b).

\section{Social domain}

Only one indicator was identified to reflect the situation of adolescent girls in the social domain, namely the attitude towards domestic violence through the acceptance of the husband hitting his wife for several reasons. Women were asked whether they considered it acceptable if a husband hits his wife if she goes out without telling him, neglects the children, argues with him, refuses to have sex with him or burns the food. An aggregate indicator was created by considering that an adolescent girl accepts domestic violence if she finds it acceptable that a husband hits his wife for at least one of the aforementioned reasons. Figures 4 and 5 present the proportions of adolescent girls (15-19) that find it acceptable for a husband to hit his wife for several reasons decomposed by respectively area, ethnicity and region. 
Figure 4 Attitude towards domestic violence in Vietnam

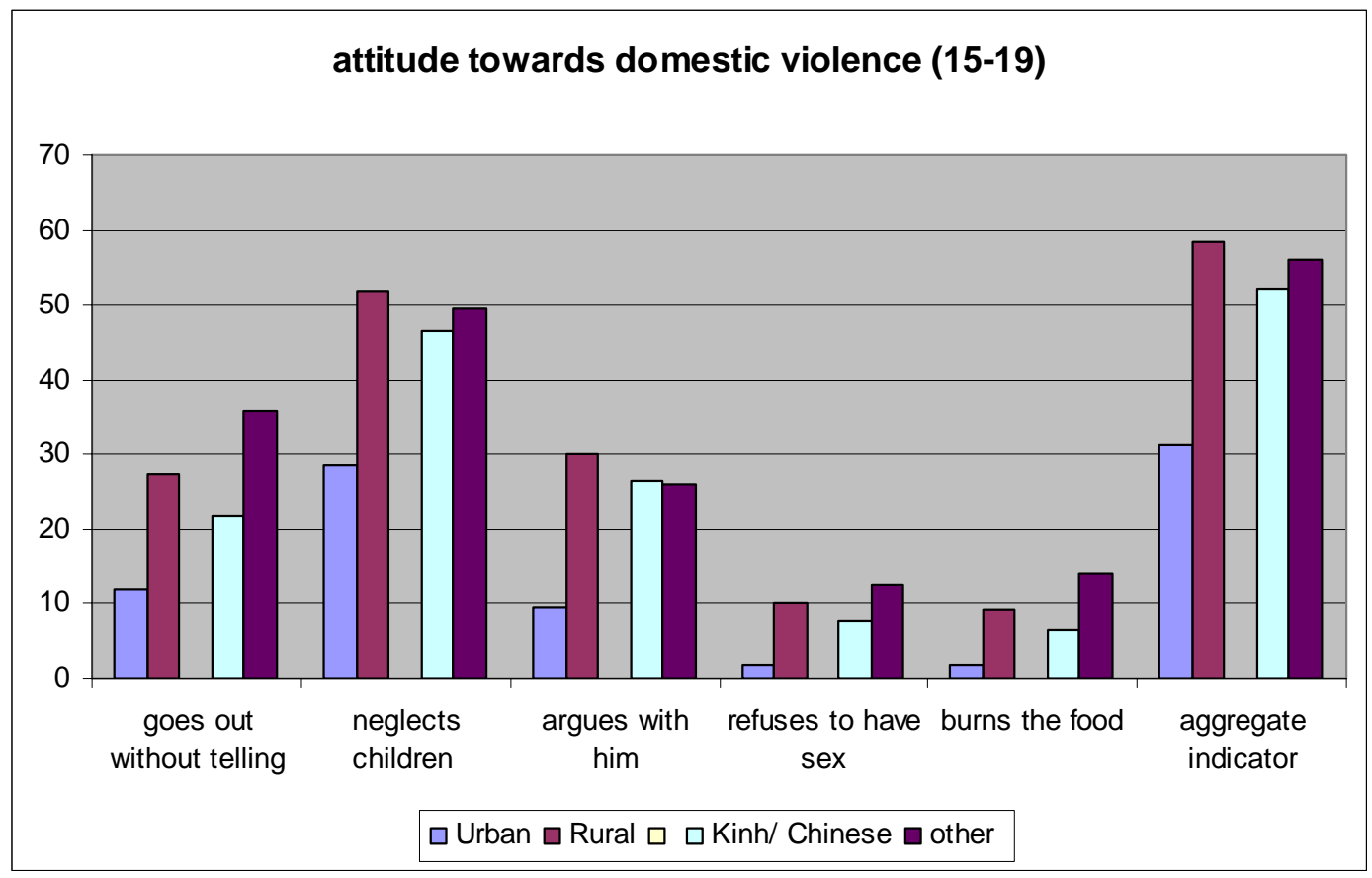

Source: author's own calculations from MICS 2006

Figure 5 Attitude towards domestic violence in Vietnam

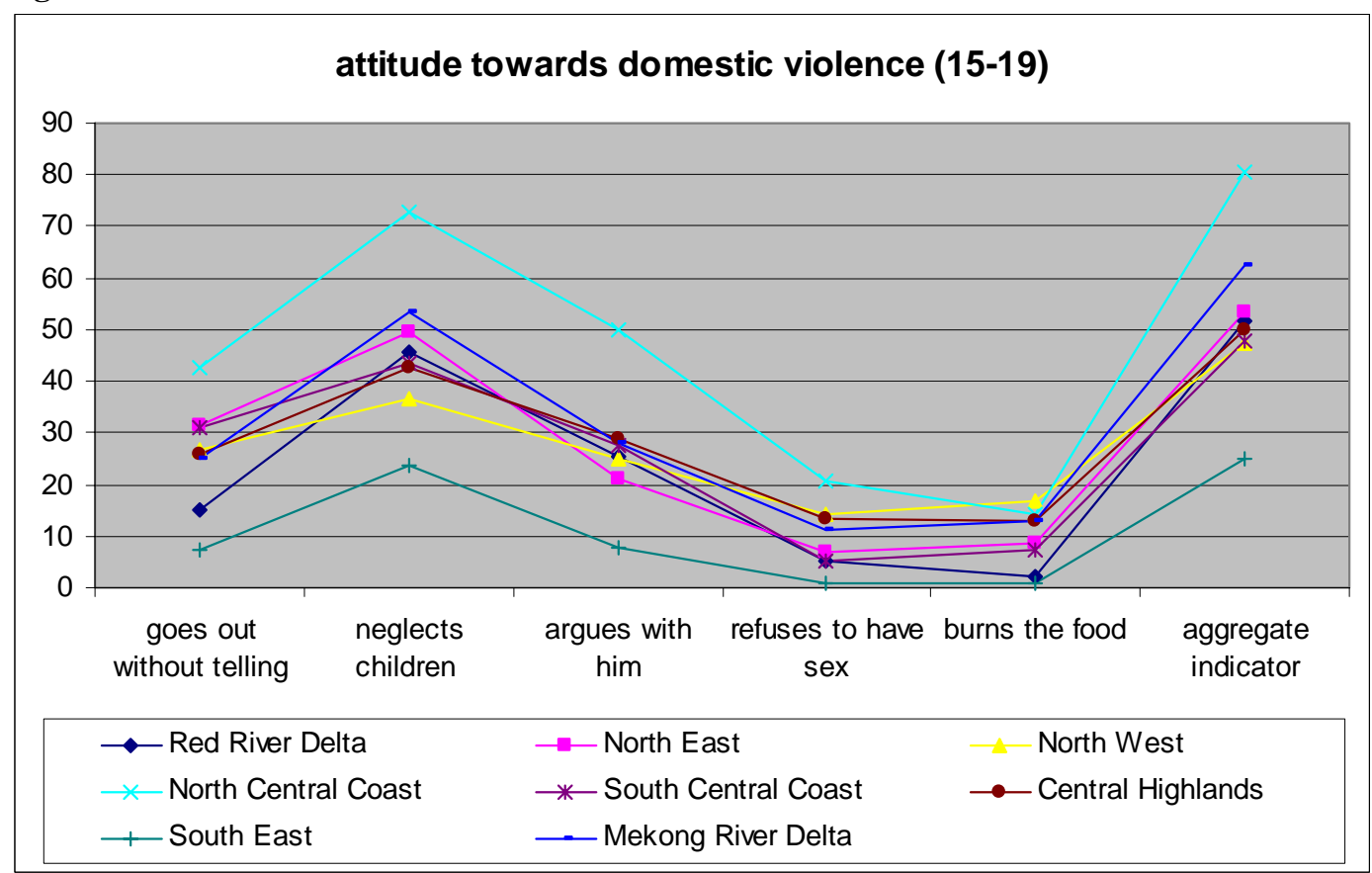

Source: author's own calculations from MICS 2006

The decompositions by various groups in society show that the attitudes towards domestic violence by adolescent women are much dispersed with its specific degree of variability depending on the specific behavior of the wife. The proportion of adolescent girls that finds it acceptable for a husband to hit his wife when she goes ranges from 7 percent in the South East region to as high as 42 percent in the North Central Coast. The acceptance of a husband hitting is wife is generally lower when a wife refuses to have sex or burns the food and highest in the case of child neglect. Domestic violence is more accepted in rural areas than urban areas across the board. This also holds with respect to ethnic minorities except for the case in which the wife 
argues with the husband. We also find considerable regional differentiation.

Acceptance of domestic violence is lowest in the South East region and highest in the North Central Coast and Mekong River Delta regions.

\section{Living environment domain}

The living environment domain allowed for the identification of the highest number of indicators. They relate to a number of basic needs, including water, sanitation, shelter conditions, assets and information. Figure 6 presents indicator rates for the sanitation and water indicators for boys and girls and points towards a large degree of gender equality. Results do, however, point towards an urban-rural divide and discrepancies between regions and minorities.

Figure 6 Access to hygienic sanitation and safe drinking water in Vietnam

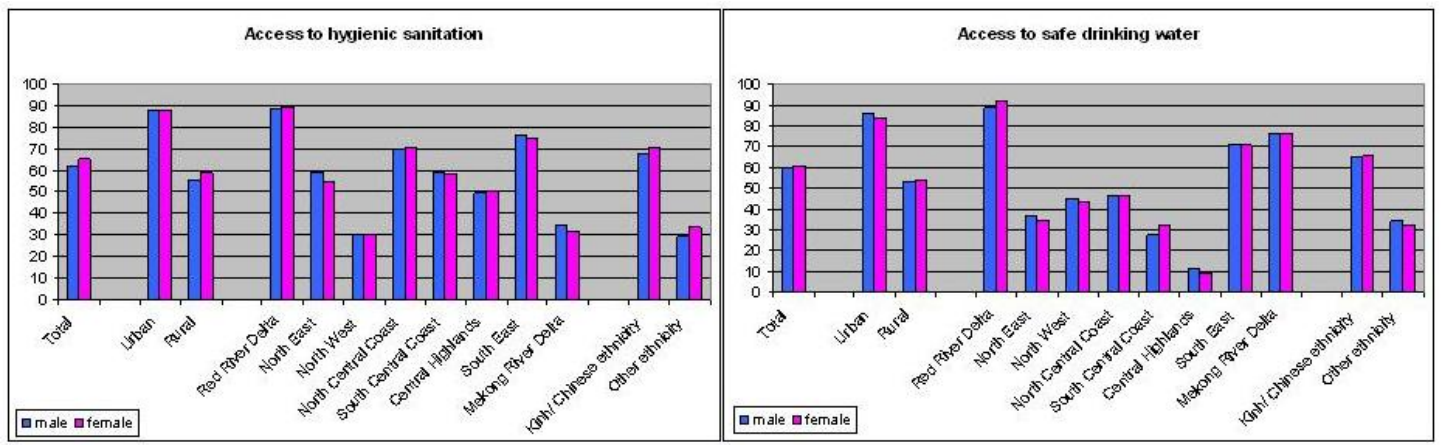

Source: author's own calculations from MICS 2006

Results in the appendix indicate that adolescent girls living in rural areas are disadvantaged with respect to the living environment in comparison to those living in urban areas. This holds for all indicators except for the availability of a TV or computer in the household. Regional estimates point towards the Red River Delta and South East regions as those with the best living environment and to the North West, Mekong River Delta and North East regions with the most disadvantaged situation. The proportions of adolescent girls living in good conditions are also considerably lower for those of ethnic minority in comparison to those of ethnic majority.

In conclusion, we find that the picture with respect to adolescent girls in Vietnam is mixed depending on the indicator under consideration and its decomposition for different groups in society. Those indicators that were available for girls and boys did not point towards the existence of persistent gender inequality. However, the interpretation of these indicators has be done with caution as they have been measured at the household level and are thus likely to show little variation at the individual level. The findings do enable the conclusion that adolescent girls in rural areas are disadvantaged in comparison to those in urban areas. A similar picture holds with respect to adolescent girls of ethnic minorities versus those of the Kinh/Chinese 
ethnicity although exceptions might be found at the indicator level. The regional picture is mixed.

\section{Conclusion}

The explorative study presented in this paper shows that an age-appropriate approach towards the measurement of well-being might have the power to give a more specific insight into issues particularly pertaining to adolescents than general approaches do. Furthermore, decomposition of results by gender and the use of indicators particularly relevant for girls allow for a gender-sensitive analysis and specific consideration of the situation of girls. The use of the MICS data in the case of Vietnam indicators indicates that such a standardized survey goes a long way in building evidence and the provision of insight into the situation of adolescent girls. Nevertheless, a lot of issues require further investigation and consideration.

First of all, we should also be critical about regarding adolescents as a single group. In light of the widespread distinction between child- and adult approaches towards poverty and well-being, the acknowledgement that adolescence is a complex developmental period and the fact that adolescence is characterized by a transition from child- to adulthood and issues pertaining to both these life stages, it might prove inappropriate to capture this is in a single concept. Other studies have also emphasized that a conflation of adolescents of different ages into a single group might mask important differences (Bearinger et al. 2007) or made a clear distinction between late and early adolescence, characterized by different levels of cognitive and sexual development (see e.g. Piaget, 2008; Impett and Tolman, 2006). One option to avoid a generalist view and expose the specific issues related to young and older adolescents is to diversify our conceptual framework and concurrent poverty and well-being approach for early and late adolescents.

A second issue requiring further investigation in future research is the consolidation of measures on objective and subjective well-being. The current dichotomy between data collection and analysis efforts make it difficult to combine both types of measures into a single approach. However, the exploration in this paper reveals that the inclusion of merely objective or subjective indicators leads to a partial picture, at best, of the situation of adolescent girls. Especially issues pertaining to the psychological domain are lacking when using a source such as a household survey, despite the particular importance of this issue in adolescence. 
References

Alkire, S. (2008). Choosing Dimensions: the Capability Approach and Multidimensional Poverty. In N. Kakwani \& J. Silber (Eds.), The Many Dimensions of Poverty. New York: Palgrave-Macmillan.

Barber, B., Eccles, J., \& Stone, M. (2001). Whatever Happened to the Jock, the Brain, and the Princess?: Young Adult Pathways Linked to Adolescent Activity Involvement and Social Identity. Journal of Adolescent Research, 16(5), 429455.

Bearinger, L., Sieving, R., Ferguson, J., \& Sharma, V. (2007). Global perspectives on the sexual and reproductive health of adolescents: patterns, prevention, and potential. The Lancet, 369, 1220-1231.

Ben-Arieh, A. (2000). Beyond Welfare: measuring and monitoring the state of children - new trends and domains. Social Indicators Research, 52(3), 235-257.

Bender, T. (1997). Assessment of Subjective Well-Being during Childhood and Adolescence. In G. Phye (Ed.), Handbook of classroom assessment: learning, achievement and adjustment: Elsevier. 
Biggeri, M. (2007, February 2007). Choosing dimensions in the case of children's wellbeing. Maitreyee, Human Development and Capability Association, Number 7.

Bradshaw, J., Hoelscher, P., \& Richardson, D. (2006). An Index of Child Well-being in the European Union. Social Indicators Research, 80(1), 133-177.

Brooks-Gunn, J., \& Duncan, G. (1997). The Effects of Poverty on Children. The Future of Children, 7(2), 55-71.

Duncan, G., \& Brooks-Gunn, J. (1997). Consequences of Growing Up Poor. New York: Russell Sage Foundation.

Duncan, G., \& Brooks-Gunn, J. (2000). Family Poverty, Welfare Reform, and Child Development. Child Development, 71(1), 188-196.

Duncan, G., Yeung, J. W., Brooks-Gunn, J., \& Smith, J. R. (1998). How Much Does Childhood Poverty Affect the Life Chances of Children? American Sociological Review, 63(3), 406-423.

Erikson, E. (1968). Identity: Youth and Crisis. New York: Norton.

Esping-Andersen, G., \& Sarasa, S. (2002). The generational conflict reconsidered. Journal of European Social Policy, 12(1), 5-21.

Furby, L., \& Beyth-Marom, R. (1992). Risk Taking in Adolescence: A DecisionMaking Perspective. Developmental Review, 12, 1-44.

Gordon, D., Nandy, S., Pantazis, C., Pemberton, S., \& Townsend, P. (2003a). Child Poverty in the Developing World. Bristol: Policy Press.

Gordon, D., Nandy, S., Pantazis, C., Pemberton, S., \& Townsend, P. (2003b). The Distribution of Child Poverty in the Developing World. Bristol, UK: Centre for International Poverty Research.

Haveman, R., \& Wolfe, B. (1995). The Determinants of Children's Attainments: A Review of Methods and Findings. Journal of Economic Literature, 33(4), 1829-1878.

Herrera, L. (2006). What's New about Youth? Development and Change, 37(6), 1425-1434.

Huebner, S. (1991). Initial Development of the Students' Life Satisfaction Scale. School Psychology International, 12, 231-240.

Huebner, S. (1994). Preliminary development and validation of a multidimensional life satisfaction scale for children. Psychological Assessment, 6, 149-158.

Huebner, S. (2004). Research on Assessment of Life Satisfaction of Children and Adolescents. Social Indicators Research, 66(1), 3-33.

Huebner, S., Drane, W., \& Valois, R. (2000). Levels and Demographic Correlates of Adolescent Life Satisfaction Reports. School Psychology International, 21(3), 281-292.

Igra, V., \& Irwin, C. (1996). Theories of adolescent risk-taking behavior. In R. DiClemente, W. B. Hansen \& L. Ponton (Eds.), Handbook of Adolescent Health Risk Behavior: Springer. 
Impett, E., \& Tolman, D. (2006). Late Adolescent Girls' Sexual Experiences and Sexual Satisfaction. Journal of Adolescent Research, 21(6), 628-646.

Kleinert, S. (2007). Adolescent healt: an opportunity not to be missed. The Lancet, 369(9567), 1057-1058.

Lesko, N. (1996). Denaturalizing Adolescence. The politics of contemporary representations. Youth \& Society, 28(2), 139-161.

Moore, K. A., Theokas, C., Lippman, L., Bloch, M., Vandivere, S., \& O'Hare, W. (2008a). A Microdata Child Well-Being Index: Conceptualization, Creation, and Findings. Child Indicators Research, 1(1), 17-50.

Moore, K. A., Vandivere, S., Atienza, A., \& Thiot, T. (2008b). Developing a Monitoring System for Indicators in Middle Childhood: Identifying Measures. Child Indicators Research, 1(2), 129-155.

Noble, M., Wright, G., \& Cluver, L. (2006). Developing a Child-Focused and Multidimensional Model of Child Poverty for South Africa. Journal of Children and Poverty, 12(1), 39-53.

Qvortrup, J. (1997). Indicators of childhood and intergenerational dimension. In A. Ben-Arieh \& H. Wintersberger (Eds.), Monitoring and Measuring the State of Children - Beyond Survival (pp. 101-112). Vienna: European Centre for Social Welfare Policy and Research.

Qvortrup, J. (1999). The Meaning of Child's Standard of Living. In A. Bowers Andrews \& N. Hevener Kaufman (Eds.), Implementing the UN Convention on the Rights of the Child: A standard of living adequate for development: Praeger Publishers.

Roelen, K., \& Gassmann, F. (2008). Measuring Child Poverty and Well-Being: a literature review. Maastricht: Maastricht Graduate School of Governance.

Roelen, K., Gassmann, F., \& Neubourg, C. d. (2009a). Child Poverty in Vietnam providing insights using a country-specific and multidimensional model. Maastricht: Maastricht Graduate School of Governance.

Roelen, K., Gassmann, F., \& Neubourg, C. d. (2009b). The Importance of Choice and Definition for the Measurement of Child Poverty- the case of Vietnam. Child Indicators Research, 2(3), 245-263.

Sells, W., \& Blum, R. (1996). Current Trends in Adolescent Health. In R. DiClemente, W. B. Hansen \& L. Ponton (Eds.), Handbook of Adolescent Health Risk Behavior: Springer.

Streeten, P. (1984). Basic Needs: Some Unsettled Questions. World Development 12(9), 973-978.

Trzcinski, E., \& Holst, E. (2008). Subjective Well-being Among Young People in Transition to Adulthood. Social Indicators Research, 97(1), 83-109.

Wagmiller, R., Lennon, M. C., Kuang, L., Alberti, P., \& Aber, L. (2006). The Dynamics of Economic Disadvantage and Children's Life Chances. American Sociological Review, 71(5), 847-866. 
White, S. (2002). Being, Becoming and Relationship: conceptual challenges of a child rights approach in development. Journal of International Development, 14(8), 1095-1104.

WHO. (2010). Child and Adolescent Health: WHO. 
Appendix

\begin{tabular}{|c|c|c|c|c|c|c|c|c|c|c|c|c|c|}
\hline & $\begin{array}{l}n=8574, \text { age } \\
10-19\end{array}$ & $\begin{array}{l}n=5114, \text { age } \\
13-19\end{array}$ & \multicolumn{4}{|c|}{$n=4399$, age $15-19$} & \multirow{2}{*}{\multicolumn{7}{|c|}{$\begin{array}{l}n=8574, \text { age } 10-19 \\
\text { Living Environment }\end{array}$}} \\
\hline & \multicolumn{3}{|l|}{ Education } & \multicolumn{2}{|l|}{ Health } & \multirow[b]{2}{*}{$\begin{array}{l}\text { Social } \\
\text { Ind. } 6- \\
\text { Attitude } \\
\text { towards } \\
\text { domestic } \\
\text { violence }\end{array}$} & & & & & & & \\
\hline & $\begin{array}{l}\text { Ind. } 1 \text { - } \\
\text { Gross } \\
\text { enrollment }\end{array}$ & $\begin{array}{l}\text { Ind. } 2 \text { - } \\
\text { Completion } \\
\text { primary } \\
\text { school }\end{array}$ & $\begin{array}{l}\text { Ind. } 3 \\
\text { Literacy } \\
\text { rate }\end{array}$ & $\begin{array}{l}\text { Ind. } 4 \text { - } \\
\text { Birth during } \\
\text { adolescence }\end{array}$ & $\begin{array}{l}\text { Ind.5- } \\
\text { Knowledge } \\
\text { about } \\
\text { HIV/AIDS }\end{array}$ & & $\begin{array}{l}\text { Ind.7 - } \\
\text { Electricity } \\
\text { in dwelling }\end{array}$ & \begin{tabular}{|l|} 
Ind.8 - \\
Proper \\
roofing
\end{tabular} & $\begin{array}{l}\text { Ind.9 - } \\
\text { Proper } \\
\text { flooring }\end{array}$ & $\begin{array}{l}\text { Ind. } 10- \\
\text { Hygienic } \\
\text { sanitation }\end{array}$ & $\begin{array}{l}\text { Ind. 11- } \\
\text { Safe } \\
\text { drinking } \\
\text { water }\end{array}$ & $\begin{array}{l}\text { Ind. } \\
12- \\
T V\end{array}$ & $\begin{array}{l}\text { Ind. } 13 \text { - } \\
\text { computer }\end{array}$ \\
\hline Total & 73.7 & 93.55 & 98.4 & 2.6 & 75.3 & 52.8 & 96.8 & 93.2 & 81.7 & 65 & 60.5 & 87.7 & 9.7 \\
\hline Urban & 86 & 98.5 & 100 & 1.4 & 76.5 & 31.2 & 99.5 & 98.4 & 932 & 88 & 835 & 879 & 37 \\
\hline Rural & 70.3 & 92.2 & 97.8 & 3.0 & 75.0 & 58.5 & 96.1 & 91.8 & 78.5 & 58.6 & 54.2 & 87.5 & 3.5 \\
\hline & & & & & & & & & & & & & \\
\hline Red River Delta & 80.67 & 99.27 & 99.6 & 2.04 & 81.63 & 51.84 & 100.00 & 98.58 & 96.63 & 89.36 & 91.84 & 94.68 & 10.46 \\
\hline North East & 61.82 & 86.8 & 96.5 & 2.65 & 78.76 & 53.54 & 90.23 & 83.86 & 59.77 & 54.39 & 35 & 71.82 & 4.77 \\
\hline North West & 58.93 & 88.77 & 96.4 & 6.05 & 79.84 & 47.58 & 76.19 & 85.32 & 35.12 & 29.84 & 43.25 & 63.49 & 1.59 \\
\hline $\begin{array}{l}\text { North Central } \\
\text { Coast }\end{array}$ & 83.98 & 98.73 & 99.5 & 1.54 & 78.97 & 80.51 & 99.82 & 95.95 & 89.08 & 70.66 & 46.3 & 87.68 & 2.46 \\
\hline $\begin{array}{l}\text { South Central } \\
\text { Coast }\end{array}$ & 73.65 & 94.12 & 97.8 & 3.75 & 59.93 & 47.94 & 99.07 & 97.77 & 92.95 & 58.13 & 31.91 & 85.34 & 9.65 \\
\hline $\begin{array}{l}\text { Central } \\
\text { Highlands }\end{array}$ & 76.42 & 87.32 & 95.3 & 2.55 & 62.98 & 49.79 & 93.81 & 97.16 & 83.78 & 50 & 9.36 & 83.78 & 5.69 \\
\hline South East & 80.13 & 96 & 99.1 & 1.29 & 78.45 & 25.00 & 99.58 & 98.33 & 94.35 & 75.1 & 70.71 & 96.86 & 22.59 \\
\hline $\begin{array}{l}\text { Mekong River } \\
\text { Delta }\end{array}$ & 61.5 & 87.72 & 98.5 & 3.94 & 70.44 & 62.56 & 96.13 & 84.74 & 64.24 & 31.74 & 76.54 & 88.61 & 10.25 \\
\hline $\begin{array}{l}\text { Kinh/Chinese } \\
\text { ethnicity }\end{array}$ & 76.4 & 95.4 & 99.3 & 2.2 & 75.3 & 52.2 & 99.1 & 95.8 & 88.6 & 70.7 & 65.7 & 92.2 & 11.4 \\
\hline Other ethnicity & 59 & 83.4 & 93.7 & 5.0 & 75.1 & 56.1 & 84.5 & 79.1 & 44.5 & 33.7 & 32.6 & 61.7 & 0.3 \\
\hline $10-12$ & 940 & $n$ & n & $n$ & n & n & 055 & 025 & 707 & 609 & 602 & 838 & 07 \\
\hline $13-15$ & 85.4 & 94.4 & 98.7 & 0 & 72.8 & 53.5 & 97.5 & 92.2 & 82.5 & 63.4 & 59.1 & 87.8 & 8.9 \\
\hline $16-19$ & 50.6 & 92.9 & 98.3 & 3.4 & 75.9 & 52.6 & 97.2 & 94.5 & 82.4 & 65.0 & 61.4 & 89.6 & 10.2 \\
\hline
\end{tabular}

Source: author's own calculations from MICS 2006 


\title{
Maastricht Graduate School of Governance
}

\author{
Working Paper Series
}

List of publications

\begin{tabular}{|c|c|c|}
\hline 2010 & & \\
\hline No. & Author(s) & Title \\
\hline 001 & Hercog, M. and A. Wiesbrock & $\begin{array}{l}\text { The Legal Framework for Highly-Skilled } \\
\text { Migration to the EU: EU and US Labour } \\
\text { Migration Policies Compared }\end{array}$ \\
\hline 002 & Salanauskaite, L. and G. Verbist & $\begin{array}{l}\text { The } 2004 \text { Law on Allowances to Children } \\
\text { in Lithuania: What do Microsimulations } \\
\text { tell us about its Distributional Impacts? }\end{array}$ \\
\hline 003 & Salanauskaite, L. & $\begin{array}{l}\text { Microsimulation Modelling in Transition } \\
\text { Countries: Review of Needs, Obstacles and } \\
\text { Achievements }\end{array}$ \\
\hline 004 & Ahmed, M, Gassmann, F. & $\begin{array}{l}\text { Measuring Multidimensional Vulnerability } \\
\text { in Afghanistan }\end{array}$ \\
\hline 005 & $\begin{array}{l}\text { Atamanov, A. and M. van den } \\
\text { Berg }\end{array}$ & $\begin{array}{l}\text { Rural non-farm activities in Central Asia: a } \\
\text { regional analysis of magnitude, structure, } \\
\text { evolution and drivers in the Kyrgyz } \\
\text { Republic }\end{array}$ \\
\hline 006 & $\begin{array}{l}\text { Tirivayi, N., J. Koethe and W. } \\
\text { Groot }\end{array}$ & $\begin{array}{l}\text { Food Assistance and its effect on the } \\
\text { Weight and Antiretroviral Therapy } \\
\text { Adherence of HIV Infected Adults: } \\
\text { Evidence from Zambia }\end{array}$ \\
\hline 007 & $\begin{array}{l}\text { Atamanov, A. and M. van den } \\
\text { Bergs }\end{array}$ & $\begin{array}{l}\text { Determinants of remittances in Central } \\
\text { Asia: evidence based on the household } \\
\text { budget survey in the Kyrgyz Republic }\end{array}$ \\
\hline 008 & Tomini, F. and L. Borghans & Between Children and Friends \\
\hline 009 & Tirivayi, N. and W. Groot & $\begin{array}{l}\text { In Kind Transfers, Household Spending } \\
\text { Behaviour and Consumption Responses in } \\
\text { HIV-affected Households: Evidence from } \\
\text { Zambia }\end{array}$ \\
\hline 010 & Tomini, F. and L. Borghans & $\begin{array}{l}\text { Interdependent transfers and individual } \\
\text { needs: } \\
\text { Parental support to children in the } \\
\text { Netherlands }\end{array}$ \\
\hline 011 & Kwanpadh Suddhi-Dhamakit & $\begin{array}{l}\text { You, Me, or Us? Conjugal Separation and } \\
\text { Parent-Child Separation in Family } \\
\text { Migration: a Case of Rural Thailand }\end{array}$ \\
\hline 012 & Florian Tomini & $\begin{array}{l}\text { Transferring to family and friends: } \\
\text { A review of the Motives, Evidence, and the }\end{array}$ \\
\hline
\end{tabular}




\begin{tabular}{|c|c|c|}
\hline & & role of Economics \\
\hline 013 & Keetie Roelen & $\begin{array}{l}\text { Girls in Transition - How to build evidence } \\
\text { and gain insight? }\end{array}$ \\
\hline \multicolumn{3}{|c|}{2009} \\
\hline No. & Author(s) & Title \\
\hline 001 & $\begin{array}{l}\text { Roelen, K., Gassmann, F. and C. } \\
\text { de Neubourg }\end{array}$ & $\begin{array}{l}\text { Child Poverty in Vietnam - providing } \\
\text { insights using a country-specific and } \\
\text { multidimensional model }\end{array}$ \\
\hline 002 & Siegel, M. and Lücke, M. & $\begin{array}{l}\text { What Determines the Choice of Transfer } \\
\text { Channel for Migrant Remittances? The } \\
\text { Case of Moldova }\end{array}$ \\
\hline 003 & $\begin{array}{l}\text { Sologon, D. and O'Donoghue, } \\
\text { C. }\end{array}$ & $\begin{array}{l}\text { Earnings Dynamics and Inequality in EU } \\
1994-2001\end{array}$ \\
\hline 004 & $\begin{array}{l}\text { Sologon, D. and O'Donoghue, } \\
\text { C. }\end{array}$ & $\begin{array}{l}\text { Policy, Institutional Factors and Earnings } \\
\text { Mobility }\end{array}$ \\
\hline 005 & $\begin{array}{l}\text { Muñiz Castillo, M.R. and D. } \\
\text { Gasper }\end{array}$ & $\begin{array}{l}\text { Looking for long-run development } \\
\text { effectiveness: An autonomy-centered } \\
\text { framework for project evaluation }\end{array}$ \\
\hline 006 & $\begin{array}{l}\text { Muñiz Castillo, M.R. and D. } \\
\text { Gasper }\end{array}$ & $\begin{array}{l}\text { Exploring human autonomy } \\
\text { effectiveness: Project logic and its effects } \\
\text { on individual autonomy }\end{array}$ \\
\hline 007 & Tirivayi, $\mathrm{N}$ and $\mathrm{W}$. Groot & $\begin{array}{l}\text { The Welfare Effects of Integrating } \\
\text { HIV/AIDS Treatment with Cash or In Kind } \\
\text { Transfers }\end{array}$ \\
\hline 008 & $\begin{array}{l}\text { Tomini, S., Groot, W. and } \\
\text { Milena Pavlova }\end{array}$ & $\begin{array}{l}\text { Paying Informally in the Albanian Health } \\
\text { Care Sector: A Two-Tiered Stochastic } \\
\text { Frontier Bargaining Model }\end{array}$ \\
\hline 009 & $\mathrm{Wu}, \mathrm{T}$., and Lex Borghans & $\begin{array}{l}\text { Children Working and Attending School } \\
\text { Simultaneously: Tradeoffs in a Financial } \\
\text { Crisis }\end{array}$ \\
\hline 010 & $\begin{array}{l}\text { Wu, T., Borghans, L. and } \\
\text { Arnaud Dupuy }\end{array}$ & $\begin{array}{l}\text { No School Left Behind: Do Schools in } \\
\text { Underdeveloped Areas Have Adequate } \\
\text { Electricity for Learning? }\end{array}$ \\
\hline 011 & Muñiz Castillo, M.R. & $\begin{array}{l}\text { Autonomy as Foundation for Human } \\
\text { Development: A Conceptual Model to } \\
\text { Study Individual Autonomy }\end{array}$ \\
\hline 012 & Petrovic, M. & $\begin{array}{l}\text { Social Assistance, activation policy, and } \\
\text { social exclusion: Addressing Causal } \\
\text { Complexity }\end{array}$ \\
\hline 013 & Tomini, F. and J. Hagen-Zanker & $\begin{array}{l}\text { How has internal migration in Albania } \\
\text { affected the receipt of transfers from } \\
\text { kinship members? }\end{array}$ \\
\hline 014 & Tomini, S. and H. Maarse & $\begin{array}{l}\text { How do patient characteristics influence } \\
\text { informal payments for inpatient and } \\
\text { outpatient health care in Albania }\end{array}$ \\
\hline 015 & Sologon, D. M. and C. & Equalizing or disequalizing lifetime \\
\hline
\end{tabular}




\begin{tabular}{|c|c|c|}
\hline & O’Donoghue & $\begin{array}{l}\text { earnings differentials? Earnings mobility in } \\
\text { the EU:1994-2001 }\end{array}$ \\
\hline 016 & $\begin{array}{l}\text { Henning, F. and } \\
\text { Dr. Gar Yein Ng }\end{array}$ & $\begin{array}{l}\text { Steering collaborative e-justice. } \\
\text { An exploratory case study of legitimisation } \\
\text { processes in judicial videoconferencing in } \\
\text { the Netherlands }\end{array}$ \\
\hline 017 & $\begin{array}{l}\text { Sologon, D. M. and C. } \\
\text { O'Donoghue }\end{array}$ & $\begin{array}{l}\text { Increased Opportunity } \\
\text { to Move up the Economic Ladder? } \\
\text { Earnings Mobility in EU: 1994-2001 }\end{array}$ \\
\hline 018 & $\begin{array}{l}\text { Sologon, D. M. and C. } \\
\text { O'Donoghue }\end{array}$ & $\begin{array}{l}\text { Lifetime Earnings Differentials? } \\
\text { Earnings Mobility in the EU: 1994-2001 }\end{array}$ \\
\hline 019 & Sologon, D.M. & $\begin{array}{l}\text { Earnings Dynamics and Inequality among } \\
\text { men in Luxembourg, 1988-2004: Evidence } \\
\text { from Administrative Data }\end{array}$ \\
\hline 020 & $\begin{array}{l}\text { Sologon, D. M. and C. } \\
\text { O'Donoghue }\end{array}$ & $\begin{array}{l}\text { Earnings Dynamics and Inequality in EU, } \\
1994-2001\end{array}$ \\
\hline 021 & $\begin{array}{l}\text { Sologon, D. M. and C. } \\
\text { O'Donoghue }\end{array}$ & $\begin{array}{l}\text { Policy, Institutional Factors and Earnings } \\
\text { Mobility }\end{array}$ \\
\hline 022 & Ahmed, M., Gassmann F., & $\begin{array}{l}\text { Defining Vulnerability in Post Conflict } \\
\text { Environments }\end{array}$ \\
\hline \multicolumn{3}{|l|}{2008} \\
\hline No. & Author(s) & Title \\
\hline 001 & Roelen, K. and Gassmann, F. & $\begin{array}{l}\text { Measuring Child Poverty and Well-Being: } \\
\text { a literature review }\end{array}$ \\
\hline 002 & Hagen-Zanker, J. & $\begin{array}{l}\text { Why do people migrate? A review of the } \\
\text { theoretical literature }\end{array}$ \\
\hline 003 & Arndt, C. and C. Omar & The Politics of Governance Ratings \\
\hline 004 & $\begin{array}{l}\text { Roelen, K., Gassmann, F. and C. } \\
\text { de Neubourg }\end{array}$ & $\begin{array}{l}\text { A global measurement approach versus a } \\
\text { country-specific measurement approach. } \\
\text { Do they draw the same picture of child } \\
\text { poverty? The case of Vietnam }\end{array}$ \\
\hline 005 & $\begin{array}{l}\text { Hagen-Zanker, J., M. Siegel } \\
\text { and C. de Neubourg }\end{array}$ & $\begin{array}{l}\text { Strings Attached: The impediments to } \\
\text { Migration }\end{array}$ \\
\hline 006 & Bauchmüller, R. & $\begin{array}{l}\text { Evaluating causal effects of Early } \\
\text { Childhood Care and Education } \\
\text { Investments: A discussion of the } \\
\text { researcher's toolkit }\end{array}$ \\
\hline 007 & $\begin{array}{l}\text { Wu, T., Borghans, L. and A. } \\
\text { Dupuy }\end{array}$ & $\begin{array}{l}\text { Aggregate Shocks and How Parents Protect } \\
\text { the Human Capital Accumulation Process: } \\
\text { An Empirical Study of Indonesia }\end{array}$ \\
\hline
\end{tabular}




\begin{tabular}{|c|c|c|}
\hline 008 & $\begin{array}{l}\text { Hagen-Zanker, J. and Azzarri, } \\
\text { C. }\end{array}$ & $\begin{array}{l}\text { Are internal migrants in Albania leaving } \\
\text { for the better? }\end{array}$ \\
\hline 009 & Rosaura Muñiz Castillo, M. & $\begin{array}{l}\text { Una propuesta para analizar proyectos con } \\
\text { ayuda internacional:De la autonomía } \\
\text { individual al desarrollo humano }\end{array}$ \\
\hline 010 & $\mathrm{Wu}, \mathrm{T}$. & $\begin{array}{l}\text { Circular Migration and Social Protection in } \\
\text { Indonesia }\end{array}$ \\
\hline \multicolumn{3}{|c|}{2007} \\
\hline No. & Author(s) & Title \\
\hline 001 & Notten, G. and C. de Neubourg & $\begin{array}{l}\text { Relative or absolute poverty in the US and } \\
\text { EU? The battle of the rates }\end{array}$ \\
\hline 002 & $\begin{array}{l}\text { Hodges, A. A. Dufay, K. } \\
\text { Dashdorj, K.Y. Jong, T. } \\
\text { Mungun and U. Budragchaa }\end{array}$ & $\begin{array}{l}\text { Child benefits and poverty reduction: } \\
\text { Evidence from Mongolia's Child Money } \\
\text { Programme }\end{array}$ \\
\hline 003 & Hagen-Zanker, J. and Siegel, M. & $\begin{array}{l}\text { The determinants of remittances: A review } \\
\text { of the literature }\end{array}$ \\
\hline 004 & Notten, G. & $\begin{array}{l}\text { Managing risks: What Russian households } \\
\text { do to smooth consumption }\end{array}$ \\
\hline 005 & Notten, G. and C. de Neubourg & $\begin{array}{l}\text { Poverty in Europe and the USA: } \\
\text { Exchanging official measurement methods }\end{array}$ \\
\hline 006 & Notten, G and C. de Neubourg & $\begin{array}{l}\text { The policy relevance of absolute and } \\
\text { relative poverty headcounts: Whats in a } \\
\text { number? }\end{array}$ \\
\hline 007 & Hagen-Zanker, J. and M. Siegel & $\begin{array}{l}\text { A critical discussion of the motivation to } \\
\text { remit in Albania and Moldova }\end{array}$ \\
\hline 008 & Wu, Treena & $\begin{array}{l}\text { Types of Households most vulnerable to } \\
\text { physical and economic threats: Case studies } \\
\text { in Aceh after the Tsunami }\end{array}$ \\
\hline 009 & Siegel, M. & $\begin{array}{l}\text { Immigrant Integration and Remittance } \\
\text { Channel Choice }\end{array}$ \\
\hline 010 & Muñiz Castillo, M. & $\begin{array}{l}\text { Autonomy and aid projects: Why do we } \\
\text { care? }\end{array}$ \\
\hline \multicolumn{3}{|c|}{2006} \\
\hline No. & Author(s) & Title \\
\hline 001 & $\begin{array}{l}\text { Gassmann, F. and } \\
\text { G. Notten }\end{array}$ & $\begin{array}{l}\text { Size matters: Poverty reduction effects of } \\
\text { means-tested and universal child benefits in } \\
\text { Russia }\end{array}$ \\
\hline 002 & $\begin{array}{l}\text { Hagen-Zanker, J. and } \\
\text { M.R. Muñiz Castillo }\end{array}$ & $\begin{array}{l}\text { Exploring multi-dimensional wellbeing and } \\
\text { remittances in El Salvador }\end{array}$ \\
\hline
\end{tabular}




\begin{tabular}{lll}
\hline 003 & Augsburg, B. & $\begin{array}{l}\text { Econometric evaluation of the SEWA Bank } \\
\text { in India: Applying matching techniques } \\
\text { based on the propensity score }\end{array}$ \\
\hline 004 & $\begin{array}{l}\text { Notten, G. and } \\
\text { D. de Crombrugghe }\end{array}$ & $\begin{array}{l}\text { Poverty and consumption smoothing in } \\
\text { Russia }\end{array}$ \\
\hline $\mathbf{2 0 0 5}$ & & Title \\
No. & Author(s) & $\begin{array}{l}\text { An Evaluation of the Welfare Impacts of } \\
\text { Electricity Tariff Reforms And Alternative } \\
\text { Compensating Mechanisms In Tajikistan }\end{array}$ \\
\hline 001 & Gassmann, F. & $\begin{array}{l}\text { How to Improve Access to Social } \\
\text { Protection for the Poor? } \\
\end{array}$ \\
\hline 002 & Gassmann, F. & $\begin{array}{l}\text { Lessons from the Social Assistance Reform } \\
\text { in Latvia }\end{array}$ \\
\hline
\end{tabular}

